\title{
Sustainable Livelihood Conditions of Farm Worker Households around Baluran National Park: Case Study in Wonorejo, Indonesia
}

\author{
Sri Rahayu Budiani, Ratri Purnama Dewi, Kurniawati, Tiara Putri Amalia, \\ Monita Deka Pratiwi, Retno Murti Andayaningrum, Ulil Usnaini, and Putri Dwi Yuliyana \\ Department of Environmental Geography, Faculty of Geography, \\ Universitas Gadjah Mada, Yogyakarta \\ Corresponding Author: Sri Rahayu Budiani (email: srahayu@ugm.ac.id)
}

\begin{abstract}
Farm workers are a group that is vulnerable to poverty and depends on weather or climatic factors. However, this profession dominates one of the villages around the Baluran National Park of Indonesia, i.e., Wonorejo, Banyuputih Subdistrict, Situbondo District, East Java. The Baluran National Park is a natural resource conservation area with a savanna ecosystem that was established in March 1980 through the Deklarasi Lima Taman Nasional (Declaration of Five National Parks) of Indonesia. It has an area of 25,000 hectares located in Banyuputih Subdistrict, Situbondo District, East Java and includes th ree villages, i.e., Wonorejo, Sumberwaru, and Sumberanyar. This study aimed to describe the sustainable livelihood conditions of farm worker households in Wonorejo. This study is a quantitative research through household surveys and is supported by in-depth interviews with expert informants. The results of this study confirmed that farm workers in Wonorejo had good access to five livelihood assets, i.e., natural, physical, human, social, and financial assets. They had also been able to survive without destroying the natural resources in Baluran National Park.
\end{abstract}

Keywords: sustainable livelihood; farm workers; wonorejo; Baluran National Park

\section{Introduction}

Advisory Committees of the United Nations (UN) identify farmers, small landowners, landless laborers, fishermen, hunters, and gatherers as one of the most discriminated against and most vulnerable groups (United Nations, 2012). What is meant by vulnerability is being vulnerable in socio-economic aspects, i.e., poverty. Such condition common happens, especially in rural areas. The occupation group is indirectly very dependent on seasonal or weather factors. If farmers or fishermen are not in favorable season or weather conditions for their activities, they will have to think of other ways or strategies to adapt and still obtain the income.

One of the rural areas dominated by this vulnerable group is Wonorejo, a village with the largest area in Banyuputih Subdistrict, Situbondo District, East Java (Statistics Indonesia in Situbondo District, 2018). The village is also a prop for its national park named Baluran National Park (Anggraeni, 2015). Although there is no regulation that 
officially confirms this, the village, which has an area of $239.19 \mathrm{~km}^{2}$, is part of the Baluran National Park (TNB) with a cultivated area directly adjacent to a natural resource conservation area (Figure 1).

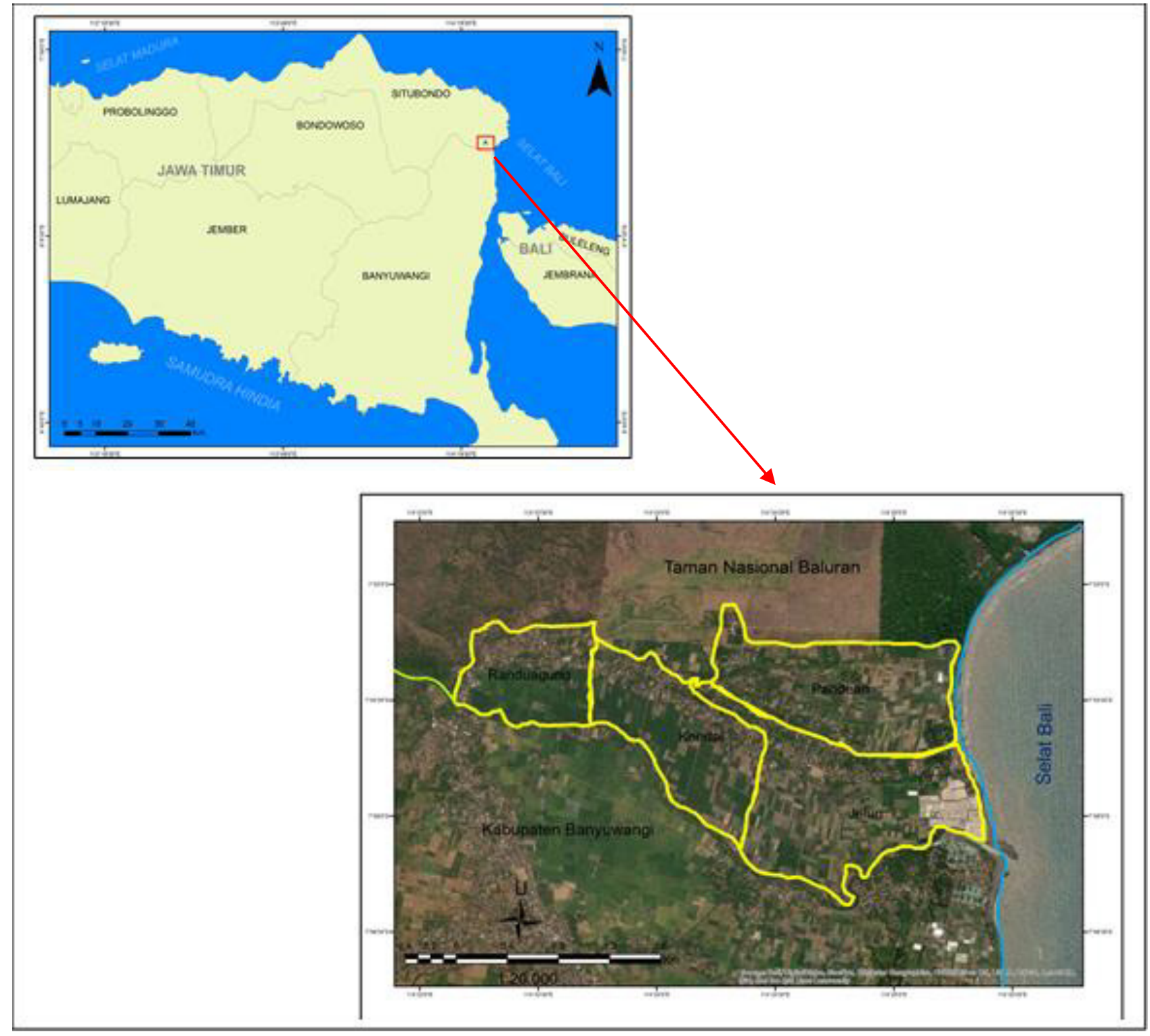

Figure 1. Map of the Research Location

Most of the Wonorejo people's livelihood is a farm worker (Statistics Indonesia in Situbondo District, 2018). Figure 2 presents agricultural farm workers rank first, followed by farmers and fishermen. It means that the agricultural sector is the foundation of the villagers. Although they are vulnerable to poverty, farm workers dominate the livelihood with fluctuating trends in the percentage, but it increases every year (Figure 3). 
Sri Rahayu Budiani, Ratri Purnama Dewi, Kurniawati, Tiara Putri Amalia, Monita Deka Pratiwi, Retno Murti Andayaningrum, Ulil Usnaini, and Putri Dwi Yuliyana

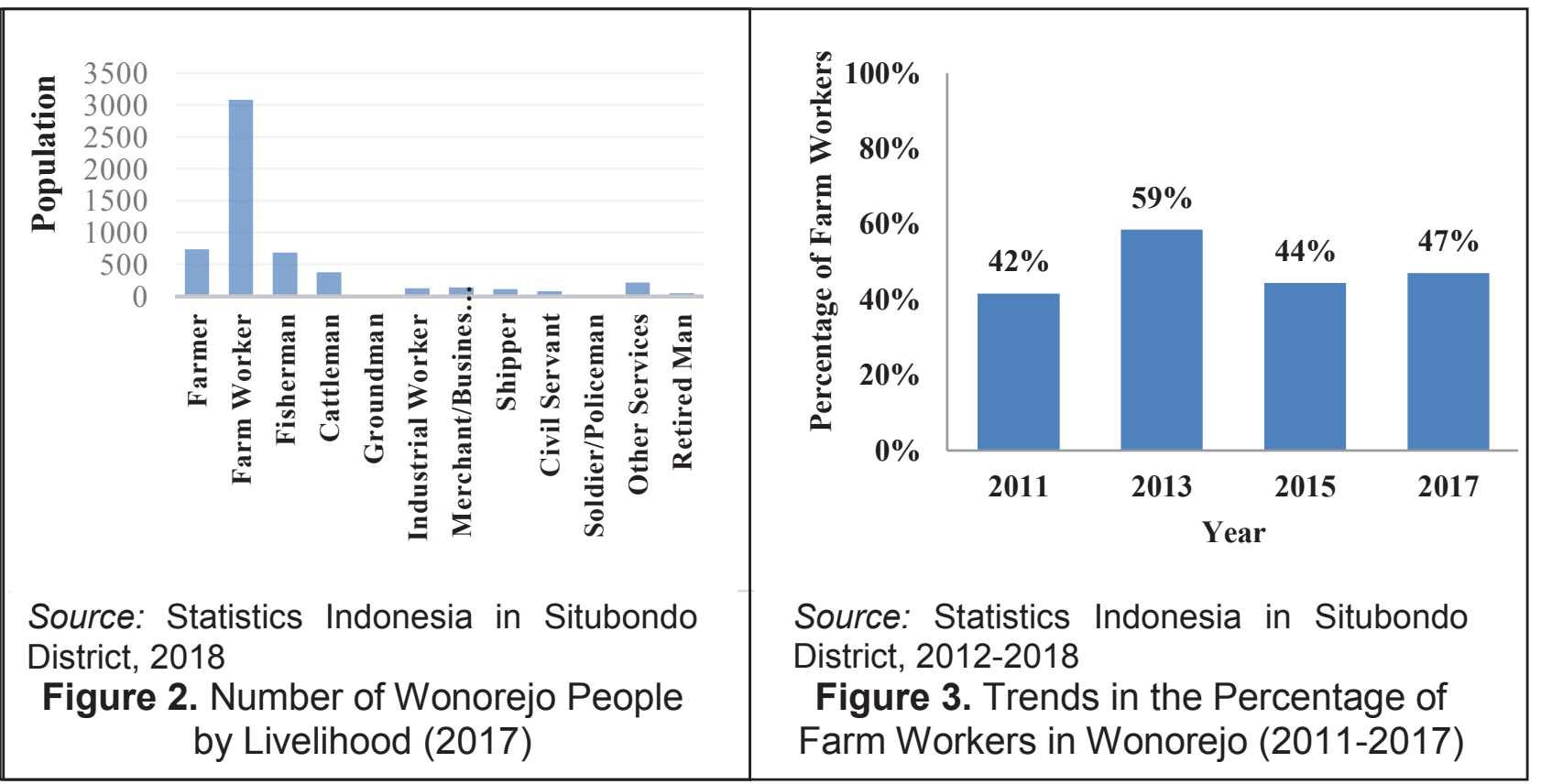

The physical characteristics of the dry area of Wonorejo are a challenge for the farm workers. Sylviani and Sakuntaladewi (2010) explained that there had been a shift in the planting season and the number of harvests, from three to two times, due to the seasonal changes in Wonorejo. The rice field irrigation from rainwater is no longer sufficient, so it requires the well water. The additional income is obtained from the use of forest products in the Baluran National Park, such as tamarind fruit (for herbal medicine), gadung, honey, palm leaves and fruit (for handicrafts), keminting, animal feed, firewood, and birds for sale. This activity is carried out throughout the year and is increasingly being carried out during the dry season. The seasonal changes that increase community pressure on forests can lead to conflicts between communities and managers of the Baluran National Park (Marliani, 2005).

As a result, one of the concrete steps taken by the Ministry of Environment in limiting the damage that occurs in the Baluran National Park is by prohibiting hunting activities for wild animals around the forest and cutting down trees and forest honey for public purposes. Communities around the national park are only given access to: (1) collect Non-Timber Forest Products; (2) traditional cultivation; (3) traditional hunting is limited to unprotected species; (4) exploiting marine resources; and (5) limited nature tourism (Regulation of the Ministry of Environment and Forestry of the Republic of Indonesia Number P.43/MENLHK/SETJEN/ KUM.1/6/2017 concerning Empowerment of Communities around Nature Reserve and Conservation Areas).

The declining quality of agricultural land and the limited access of the community to forest products in the Baluran National Park make the livelihood conditions among farm worker households significant to observe. The inhabitants who were initially still able to make ends meet through the natural resources of the Baluran National Park forest, have been limited now so that they must have other alternative resources to survive. Scoone (1998) explained that a livelihood is said to be sustainable if they can cope with and recover from stresses and 
shocks, maintain, or increase their capacity and capital, without destroying the natural resource base. A sustainable livelihood is achieved through access to a variety of living resources (natural, economic, human, and social capital) which are combined in pursuit of different livelihood strategies (intensification or expansion of agriculture, diversification of livelihood, and migration). Such concept of sustainable livelihood emphasizes the analysis of various formal and informal organizational and institutional factors that influence sustainable livelihood outcomes.

It is then hoped that they will be able to see the extent to which farm workers access various sources of life through a study of the sustainable livelihood conditions of farm worker households in Wonorejo, thus they are able to survive. This study aimed to describe the sustainable livelihood conditions of farm worker households in Wonorejo, Banyuputih Subistrict, Situbondo District, East Java. This study did not only find information related to farm workers' access to their livelihood resources, but also analyzes the formal institutional role of Baluran National Park in particular.

\section{Methods}

The approach used in this study was the approach of access to livelihood resources initiated by Scoone (1998) and was complemented by guidance from DFID (1999) in a book entitled Sustainable Livelihood Guidence Sheets. There were five types of livelihood resources that had been examined, i.e., natural capital, physical capital, social capital, human capital, and financial capital. The concept of sustainable livelihood that had been observed also needed to take into consideration for the formal institutional role of the Baluran National Park, so it could find whether the farm workers in Wonorejo already had sustainable livelihood or not.

This study was conducted in October 2019 in Wonorejo, Banyuputih Subdistrict, Situbondo District, East Java. There are four hamlets in Wonorejo, i.e., Randuagung, Kendal, Jelun, and Pandean. The administrative boundaries of Wonorejo are Sumberwaru (Situbondo District) in the north and west, Bajulmati (Banyuwangi District) in the south, and Bali Strait in the east. Wonorejo was chosen as the research location since it is the largest village in Banyuputih Subdistrict, Situbondo District, East Java, where most of the residents' livelihood are farm workers. It showed that farm workers are a group that is vulnerable to poverty, but its population dominates with a fluctuating trend that tends to increase. It is significant and interesting to observe, especially in relation to the livelihood conditions that enable them to survive without destroying the environment around the Baluran National Park.

This research is a quantitative study with a sampling method. The analysis unit used in this study is households, which according to the Statistics Indonesia, included in a group of people who usually live together in a building with the food management eating in one kitchen. Meanwhile, the population in this study is farm worker households with a total of 353 people. The population was then used as the basis for calculating the number of samples, resulting in 76 samples of the households. The calculation of the number of samples was determined using the KrecjieMorgan formula with a modified $90 \%$ degree of confidence. A simple random sampling was also used as the sampling method in this study.

$3.841 \times N(0.5 \times 0.5)$

$$
\overline{(N-1) 0.10^{2}+3.841(0.5 \times 0.5)}
$$


Sri Rahayu Budiani, Ratri Purnama Dewi, Kurniawati, Tiara Putri Amalia, Monita Deka Pratiwi, Retno Murti Andayaningrum, Ulil Usnaini, and Putri Dwi Yuliyana

Beside the structured interviews, indepth interviews were also conducted with informants and secondary data collection to obtain a comprehensive analysis. The in-depth interviews were conducted to the Baluran National Park managers and counselors, as well as the village head of Wonorejo. Meanwhile, secondary data collection was obtained from the Wonorejo government office in the form of "Profile of Wonorejo in 2017" and the official website of the Statistics Indonesia provided in "Kecamatan Banyuputih Dalam Angka" or Banyuputih Subdistrict in Figures. The data were then processed and analyzed using quantitative descriptive analysis techniques and qualitative descriptive analysis.

Based on the approach used in this study, the household survey method was aimed at obtaining data on farm workers' access to livelihood resources in the form of natural, physical, human, social, and financial capital. The in-depth interview and secondary data collection were aimed at obtaining data on the role of formal institutions from the Baluran National Park towards the livelihood sustainability of farm workers. Both methods had been adapted to DFID (1999) guidelines on the study of sustainable household livelihood conditions, not only focusing on community access to livelihood resources, but it was also supported by institutional roles to create sustainable livelihood.

\section{Discussion}

The farm worker households in Wonorejo are, in general, currently facing various livelihood problems. There were two major constraints faced by the farm workers, i.e., constraints that are related to weather or climate and constraints that are not. More than half of the farm workers admitted that they only rely on non-technical irrigation from rainwater. It caused a limited period of cultivating the land. The land could only be cultivated in the rainy season.
When the dry season came, they were finally unemployed, unable to farm. Such condition was exacerbated by the lack of job vacancies, making it increasingly difficult for the farm workers to get the income. Also, the presence of plant pests also worsened the situation since they would lose due to crop failure. Due to the restrictions on access to natural resources in the Baluran National Park, most of the farm worers had never made a living from the forest anymore and they only relied on their livelihood assets. Below is the description of farm workers' access to livelihood assets in Wonorejo.

\section{Natural Resource Capital}

Most of the farm workers in Wonorejo made use of agricultural land even they did not own it. They could only rent the land or cultivate other people's land. Some of them admitted that the use of agricultural land is insufficient to fulfill their daily needs. Therefore, they found other efforts to support their livelihood, one of them is make use of the forest products from the Baluran National Park in a small amount only. Twenty four percent of the farm workers used the forest products they usually took, such as fruit, firewood, grass, kroto, and so on. The forest products, such as firewood, is taken every day. This is also in accordance with the previous research which showed that the Natural Resources of Baluran National Park that can be used throughout the year are firewoods, palms, and ant eggs, while tamarind, honey, grass, and arabica (acacia seeds) are only taken at certain months. The extraction of forest products is also limited to forest products that have fallen to the ground. People are prohibited from directly taking forest products from the trees.

In addition to utilizing forest products, fourteen percent of the farm workers also used marine products from the Bali Strait. This activity was carried out by the head of the household and other members of the 
household. This activity had less intensity than the use of agricultural land. Fishing is usually performed during the rainy season, from December to February, because of the abundance of fish during these months.

\section{Physical Capital}

The physical capital of farm workers in Wonorejo illustrates how the status of home ownership, vehicle ownership and vehicle types of the farm worker households as well as the distance from the residence to public facilities, such as health services or puskesmas, traditional markets, and educational facilities, i.e., Senior High School or typical school. Based on the status of home ownership, $96 \%$ of the farm workers in Wonorejo owned houses with their own status. It means that there were still $4 \%$ of the farm worker households who did not have their own houses, and this reflects the economic condition that was still lacking. Based on the ownership of private vehicle, $94.7 \%$ of the farm worker households in Wonorejo already had private vehicles, both bicycles and motorbikes.

The private vehicle owned by each farm worker made the access to public facilities in Wonorejo easier to reach. This is also supported by the relatively close distance between people's houses and public facilities, for instance, the existence of public transportation and puskesmas located near the gate of Wonorejo. The average distance of farm worker households to the public transport facilities and the puskesmas is 3.5 kilometers. The closer the residence is to the main village gate, the closer the residence is to public facilities, and vice versa. The closest hamlet to public facilities is Randuagung which is located at the western part of Wonorejo, adjacent to the Java-Bali highway and the main gate of the Baluran National Park.

Regarding the other public facilities, such as economic facilities, the distance between the farm workers' residence and the traditional market is around 4.5 kilometers which becomes the main market located in Banyuwangi, a district near Situbondo. Wonorejo has a traditional market, but it is classified as underdeveloped one since it cannot compete with Banyuwangi's main market. Regarding the educational facilities, Wonorejo is classified as a developed village since the Senior High Schools, i.e., SMA and SMK, are in the middle of the village. The distance to education facilities (SMA/SMK) is less than 2 kilometers, so it is not an obstacle for school-age residents to attend the school at a higher level.

\section{Human Capital}

Human capital is related to all aspects of human capital owned by farm workers, including education, skills, and health conditions. Based on the educational aspect, most of the household heads of the farm workers did not complete formal elementary school education. Meanwhile, participation in non-formal education was poor as shown by the percentage of the participation of the household members in various trainings, i.e., only $24 \%$. Regarding the trainings, most of the farm workers stated that there was no information about the trainings in Wonorejo.

The percentage of expertises or skills of farm workers in Wonorejo was not much different from that of in the training. There were only $28 \%$ of the household members who had special skills. Their skills included the ability to head seaward, massage, do mechanical things (technicians), sew, and make certain dishes for sale. These expertises are not directly related to the farm working, but it is used as a side job in fulfilling the household needs of the farm workers.

The quality of human resources can also be seen from the knowledge of technology, one of them is the internet. They could obtain any information to increase their productivities through internet. The percentage of the use 
Sri Rahayu Budiani, Ratri Purnama Dewi, Kurniawati, Tiara Putri Amalia, Monita Deka Pratiwi, Retno Murti Andayaningrum, Ulil Usnaini, and Putri Dwi Yuliyana

of internet by farm worker households was only $57 \%$, there were $43 \%$ of the farm worker households who had not used the internet. The poor use of the internet was caused by a low economic level in most of the farm worker households, so they were unable to access the internet. Besides, among the heads of farm worker households, age was a separate obstacle in using the internet since their average age was more than 30 years old. Also, it was caused by the characteristics of the villagers who did not really care about the advances in technology, for instance, the internet made them less painstaking in learning.

The human capital owned by the farm worker households can also be seen from the health condition. Health has an influence in developing an area (Sanggelorang, et al., 2015). The farm worker households in Wonorejo, where all members were in a healthy condition, reached $65 \%$ only. Thirty five percent of the farm worker households had the sick household members. Such condition was exacerbated by the low health insurance for each member. Many of them had health insurance but they did not know the validity period of the health insurance. Meanwhile, there were quite a lot of farm workers who did not have health insurance, i.e., $42.1 \%$.

\section{Financial Capital}

The financial capital owned by the farm worker households in Wonorejo can be seen from the ownership of savings, debt, or other sources of earning other than income. There were $80.30 \%$ of the farm worker households in Wonorejo who already had various types of savings. The percentage of their ownership of each saving type is presented in Figure 4.

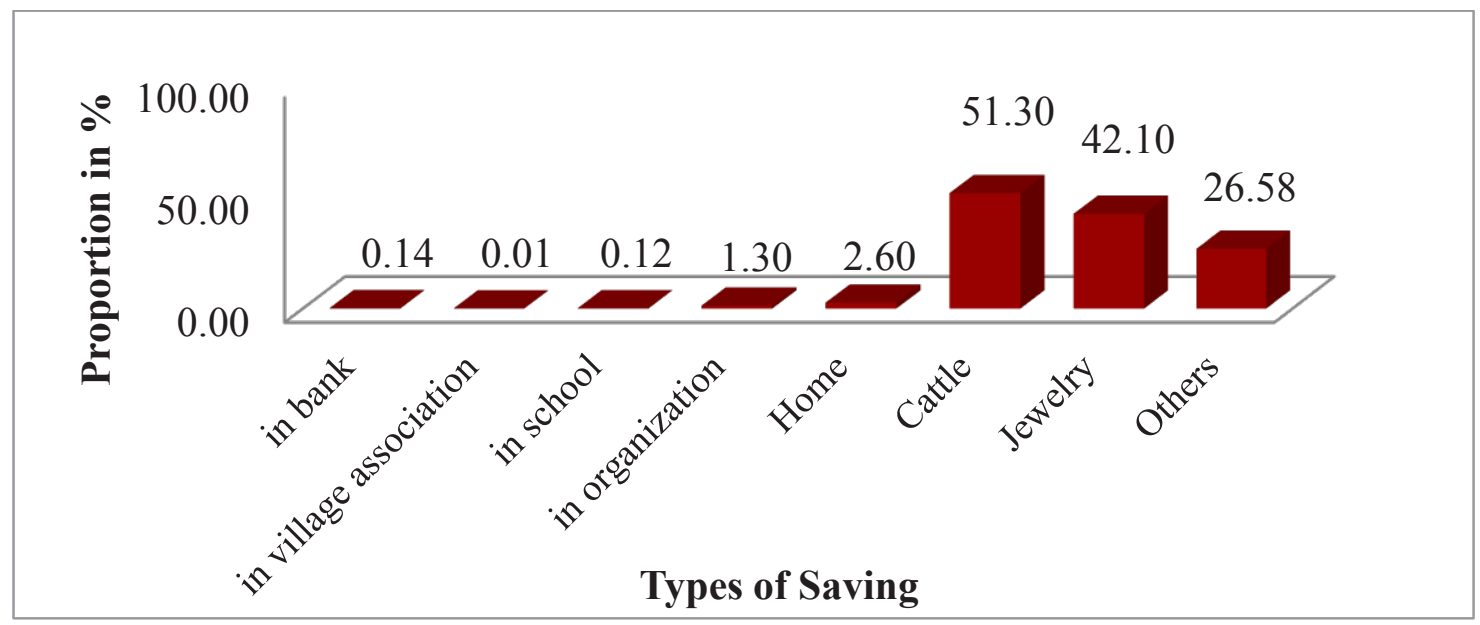

Source: Processed Primary Data, 2019

Figure 4. Percentage of Saving Types Owned by the Farm Worker Households in Wonorejo

Figure 4 indicates that more than 50\% of the farm worker households had savings in the form of livestock. The livestocks concisted of chickens or poultry, goats, and cows. Another type of saving that many farm worker households also had is jewelry $(42.10 \%)$ that was stored or used.
The type of saving mostly had by the farm worker households after jewelry are, for instance, the monthly social gatherings called arisan which is regularly held. Even though they did not have an exact time related to when they would get the money from the arisan, it is still considered as savings since 
the money obtained from arisan is quite big and can be used for the secondary needs allocation in the household. The farm worker households who had savings in the form of money were less than those who had savings not in the form of money. The money earned from the main occupation was only enough to meet their primary needs, so there was no opportunity for the farm worker households to save the small amounts of their money.

The farm worker households in Wonorejo did not only have a high percentage of savings ownership, but also a high percentage of debt ownership of $56.6 \%$. This is contradictory, but it showed the real conditions. The debt ownership was one of the steps or efforts used to meet the farm worker households' needs, both primary and secondary needs. The needs related to high or sudden expenditure caused the households need high amount of money soon. They then borrowed various loan sources, such as banks, relatives, neighbors, shops, and so on. The percentage of debt ownership in each source is presented in Figure 5.

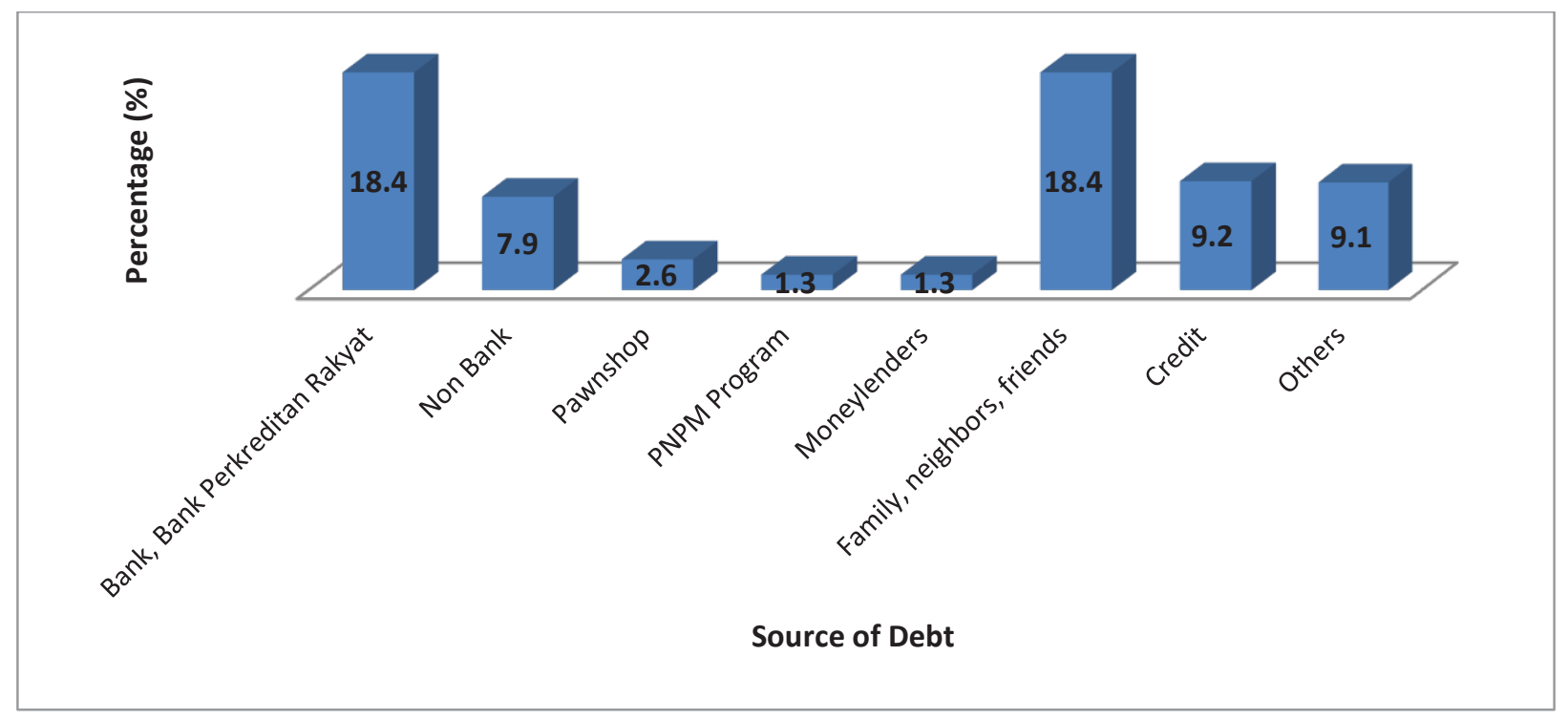

Source: Processed Primary Data, 2019

Figure 5. Percentage of Types of Debt Sources for Farm Worker Households in Wonorejo

Another source of finance other than savings and debt was assistances from the government. Sixty and half percent of the farm worker households in Wonorejo received the assistance from government that vary, both in the form of economic assistance, education assistance, and health assistance. The health assistance was the government assistance that was mostly owned by the farm worker households provided in the form of health insurance, Jamkesmas, and free BPJS.
Meanwhile, the economic assistance was in the second position that many farm worker households had. Most of this assistance was not in the form of money, but 10 kilograms of rice per month. Apart from these two assistances, educational assistance was the type of assistance that was at least owned by the farm worker households since most of the farm workers were elderly, so they did not have children who were still attending school. 
Sri Rahayu Budiani, Ratri Purnama Dewi, Kurniawati, Tiara Putri Amalia, Monita Deka Pratiwi, Retno Murti Andayaningrum, Ulil Usnaini, and Putri Dwi Yuliyana

\section{Social Capital}

Social capital is the ability of an individual or a group to interact with other individuals and groups (Hizbaron, et al., 2014: 112). An interaction that exists in community organizations helps an individual or a group to develop their insights and soft skills. Organizations are also able to collect several aspects in the form of socio-culture, economic capacity, access to services, freedom of opinion, and access to politics. The results indicated that the participation of farm worker household members in organizations in Wonorejo was not high, amounting to $37 \%$ only.

The organizations that were followed by the farm worker households involved livestock groups, neighborhood-level associations, and other organizations that were joined by the farm workers' children at the schoolage level. Meanwhile, the participation of the farm worker households in community activities was quite high, amounting to $74 \%$. The community activities that were mostly attended by the farm worker households' members were community service or mutual assistance, religious activities (e.g., tahlilan, muslimatan, and the like), and other activities. Such activities became places for the community to gather and interact to share information that existed in Wonorejo and other information related to problems in the surrounding area. Also, the activities became places to increase a harmony among residents as a manifestation of the meaning of "Desa Kebangsaan" or National Village. Wonorejo is known as "Desa Kebangsaan" because it is a village that maintains and upholds national values. It has people with any kinds of religious, ethnic, and language backgrounds. The biggest tribes living in Wonorejo are the Madurese and Javanese, while the religions believed the most by the Wonorejo people are Islam and Christian.

Another social capital owned by the farm worker households was an intimacy between household members and village officials. Fifty three percent of the farm worker households' members in Wonorejo were familiar with the village officials. Such intimacy was bond due to the frequent meetings since they lived in the same hamlet area. The farm worker households or their members often meet with the head of hamlet to discuss various matters, whether related to government, profession, or entertainment, i.e., joint exercise.

The five livelihood assets owned by the farm workers in Wonorejo illustrate that, in general farm, they have very limited capitals from a financial perspective. Also, with tha natural resource capital, it is only limited to leasing agricultural land. Although Wonorejo is rich with its natural resources, i.e., forests in the Baluran National Park and sea in the Bali Strait, the farm workers tend to be less dependent on both. Moreover, it is strengthen by the issuance of regulations restricting the use of the Baluran National Park resources stipulated in the Regulation of the Minister of Environment and Forestry of the Republic of Indonesia Number P.43/MENLHK/SETJEN/ KUM.1/6/2017 concerning Community Empowerment around Nature Reserve Areas and Nature Conservation Areas (Anonymous, 2017). It shows that the livelihood of the Wonorejo farm workers are sustainable since they could raise from the economic pressure without damaging the surrounding environment and remained obedient to laws and regulations.

The above finding is in line with the statement of the local village head that the presence of laws and regulations is sufficient to reduce community dependence on the Baluran National Park. The Baluran National Park office as an extension of the government's role also continues to make community empowerment. The community must still be able to continue their life even though they do not directly connect to the forest of Baluran National Park. Some of the community empowerment programs that had 
been implemented are farmer assistance, counseling through community forums, and the establishment of homestays as the lodging facilities for tourists. The presence of homestays is seen to be one of the new economic sources that benefit the community. However, the empowerment was not evenly provided yet to all levels of society, one of them is agricultural labor. The farm workers still felt that they were marginalized because they had not been much involved in the forums held by the Baluran National Park officers.

\section{Conclusion}

The sustainable livelihood conditions for farm laborers in Wonorejo Village can generally be seen from their access to five livelihood assets, i.e., natural resource capital, physical capital, human capital, social capital, and financial capital. Although the farm workers did not fully have natural resource capital in the form of agricultural land, they could still cultivate agricultural land using a leasing system. When they faced with a difficult livelihood situation, some of the farm workers changed their profession to become fishermen and some made use of the forest products from the Baluran National Park by following the regulations. It means that they have been able to survive without destroying the natural resources. Of the five aspects of livelihood capital, the social and physical capitals play a quite dominant role for the farm workers in Wonorejo due to the nature of a good cooperation and respect, thus they can live in harmony. The complete physical facilities also provide a support for the farm workers to live a better life. However, the formal institutional role of the Baluran National Park Office for the farm workers' livelihood has not been fully felt. It then becomes a challenge in the future to continue developing an equitable community empowerment, given the important role of institutions as a support system for sustainable livelihood.

\section{References}

Anggraeni, Y. 2015. Pola Pemanfaatan dan Kontribusi Hasil Hutan Terhadap Pendapatan Masyarakat Desa Penyangga Taman Nasional Baluran. (Undergraduate Thesis). Jember: Faculty of Agriculture, Universitas Jember.

Anonim. 2017. Peraturan Menteri Lingkungan Hidup dan Kehutanan Republik Indonesia Nomor P.43/MENLHK/SETJEN/ KUM.1/6/2017 Tentang Pemberdayaan Masyarakat di Sekitar Kawasan Suaka Alam dan Kawasan Pelestarian Alam. Jakarta: Ministry of Environment and Forestry of the Republic of Indonesia.

DFID. (1999). Sustainable livelihoods Guidance Sheets. Department for International Development, http://www. livelihoods.org/.

Hizbaron, D.R., Rina, D.A dan Yosi, S.M. (2014). "Modal Sosial dalam Manajemen Bencana Erupsi Gunungapi Merapi 2010". Modal Sosial dalam Manajemen Bencana. Editor R. Rijanta, Dyah R.H dan M. Baiquni. Yogyakarta: Gadjah Mada University Press.

Marliani, R.N. 2005. Studi Pemanfaatan Sumberdaya Hutan Oleh Masyarakat Desa Penyangga Taman Nasional Baluran. (Undergraduate Thesis). Bogor: Faculty of Forestry, Agricultural Institute of Bogor.

Saggelorang, S.M.M.; A. R. Vekie dan F. D. J. S. Hanly. 2015. "Pengaruh Pengeluaran Pemerintah di Sektor Pendidikan dan Kesehatan Terhadap Indeks Pembangunan Manusia di Sulawesi Utara". Jurnal Berkala IImiah Efisiensi,15(2), 1-11.

Scoones, I. 1998. "Sustainable Rural Livelihoods: A Framework for Analysis". IDS Working Paper 72. Institute of Development Studies.

Statistics Indonesia in Situbondo District. 2018. "Kecamatan Banyuputih dalam 
Sri Rahayu Budiani, Ratri Purnama Dewi, Kurniawati, Tiara Putri Amalia, Monita Deka Pratiwi, Retno Murti Andayaningrum, Ulil Usnaini, and Putri Dwi Yuliyana

Angka 2018". (Final Report). Situbondo:

Statistics Indonesia in Situbondo District.

Sylviani dan Sakuntaladewi, N. 2010.

"Dampak Perubahan Musim dan Strategi

Adaptasi Pengelola dan Masyarakat

Desa Sekitar Taman Nasional Baluran". Jurnal Penelitian Sosial dan Ekonomi Kehutanan, 7(3), 155-177.

The United Nations. 2012. "Studi Final tentang Pemajuan Hak Asasi Petani dan Masyarakat yang Bekerja di Daerah Pedesaan". (Document). General Assembly. Advisory Committee. 